\title{
ANTIBACTERIAL EFFECTS OF STAPHYLOCOCCUS HYICUS AND STAPHYLOCOCCUS CHROMOGENES
}

\author{
B. SKALKA \\ Department of Microbiology and Immunology \\ University of Veterinary and Pharmaceutical Sciences, 61242 Brno
}

Received August 26, 1992

\begin{abstract}
Skalka B.: Antibacterial Effects of Staphylococcus hyicus and Staphylococcus chromogenes. Acta vet. Brno, 62, 1993: 39-47.

Antibacterial effects of Staphylococcus hyicus (40 strains) and Staphylococcus chromogenes (20 strains) were tested on living and heat-devitalized cells of micrococcal, staphylococcal, streptococcal and corynebacterial indicator strains. All $S$. hyicus and $S$. chromogenes strains inhibited the growth of Micrococcus sedentarius and lysed devitalized cells of Micrococcus lylae but did not affect dead cells of $M$. sedentarius and only few of them inhibited the growth of $M$. lylae. Only a small number of $S$. hyicus strains produced intense effects on living indicators and had only very weak effects on their dead cells. The activity of some $S$. chromogenes strains, observed invariably on living indicators, did not reach the intensity recorded for active $S$. hyicus strains. Most $S$. hyicus and $S$. chromogenes strains were inactive towards the indicators. It is concluded that the antibacterial activity observed in the study should be ascribed to the characteristics of the individual strains and not to the general characteristics of $S$. hyicus and $S$. chromogenes species.
\end{abstract}

Staphylococcus hyicus, Staphylococcus chromogenes, antibacterial effects, staphylococcal, micrococcal, streptococcal and corynebacterial indicator strains

Staphylococcal exosubstances showing antibacterial activity are represented both by lytic enzymes, lysozyme (Welsch 1959) affecting some micrococci, lysostaphin (Schindler and Schuhardt 1964) affecting staphylococci, and by substances having bactericidal or bacteriostatic effects, staphylococcins (Fredericq 1946), bacteriocin-like substances (Ivanovics 1962), micrococcins ( $\mathrm{Su}$ 1948) and antibiotics of low molecular weight (Halbert et al. 1953). Recently added to the afore-mentioned substances have been exosubstances of the species Staphylococcus hyicus nad Staphylococcus chromogenes. The first report of the antibacterial activity of $S$. hyicus and $S$. chromogenes (Balus ek and Hájek 1985) described bactericidal and bacteriolytic activity observed in some strains of these two species. The lytic effects in particular then stimulated the interest of further investigators. Müller and Blobel (1987) reported that a S. hyicus strain produced a bacteriolytic enzyme whose highly purified fractions, LE IIIa and LE IIIb, exerted intense effects on devitalized cells of some streptococci, staphylococci and micrococci. Subsequent studies not only confirmed the lytic effects of LE IIIb but also recommended the utilization of this lytic enzyme for extraction of both group and type specific streptococcal antigens (Frede et al. 1989; Lämmler and Wibawan 1990). It was suggested that the production of the lytic enzyme should be regarded as a constant trait of $S$. hyicus suitable for routine identification of this species (Lämmler 1989, 1991a). The production was also described in S. chromogenes and its antigenic identity with the lytic enzyme of $S$. hyicus was demonstrated (Lämmler 1991b).

The present study was designed to test the antibacterial effects of $S$. hyicus and $S$. chromogenes on micrococcal, staphylococcal, streptococcal and corynebacterial species with reference to possible practical utilization of these effects.

\section{Materials and Methods}

\section{Culture Media}

Brain Heart Infusion Agar CM 375 (Oxoid Ltd.) and Blood Agar Base No. 4 (Imuna) were used. 
Bacterial Strains

Strains Tested for Antibacterial Activity

The set of strains examined comprised 40 strains of Staphylococcus hyicus and 20 strains of Staphylococcus chromogenes. The $S$. hyicus strains were $M 51 / 88$ (664/86), M 52/88, M 53/87, M 69/89 and 36 other strains chosen at random from the laboratory collection of the author. The $S$. chromogenes strains were $M 45 / 88$ (703/87), M 46/88, M 47/88 and 17 other strains chosen at random from the laboratory collection of the author.

\section{Control Staphylococcal Active Strains}

S. aureus Mau 89/79 (UT0007), producer of bacteriocin Bac $R_{1} ; S$. sciuri M 32/86 (KPJ III), producer of a wide-spectrum staphylococcin; and $S$. simulans biovar Mau 108/96 (K-6-WI), producer of lysostaphin, were used as controls.

\section{Indicator Strains}

Of the genus Micrococcus the following strains were used: $12 \mathrm{M}$. luteus strains, namely CCM 169 (Mlu), CCM 410, CCM 3394 and 9 other strains isolated in our laboratory; 5 M. lylae strains, namely CCM 2693 (Mly), CCM 2695 and 3 other strains isolated in our laboratory; 5 M. roseus strains, namely CCM 839 (Mro), CCM 676 and 3 other strains isolated in our laboratory; $3 M$. sedentarius strains, namely CCM 2697 (Mse), CCM 2698 and 1 strain isolated in our laboratory; $3 M$. varians strains, namely CCM 884 (Mva) and 2 strains isolated in our laboratory; and 1 strain each of M. kristinae and M. nishinomiyaensis, namely CCM 2690 (Mkr) and CCM 2140 (Mni), respectively.

Of the genus Staphylococcus the following strains were used: S. aureus Mau 106/86 (Sa1), Mau 28/58 (Sa2), Mau 105/86 (Sa3), Mau 104/86 (Sa4) and Mau 124/89 (Sa5); S. intermedius M 37/86 (Si1) and M 38/86 (Si2); and $S$. haemolyticus $M$ 39/86 (Shi).

Of the genus Streptococcus the following strains were used: S. agalactiae CCM 6187 (Sag) and 3 other strains isolated in our laboratory; S. uberis CCM 6186 (Sub) and 3 other strains isolated in our laboratory; S. equi CCM 5532 (Seq) and 3 other strains isolated in our laboratory.

Of the genus Corynebacterium the following strains were used: C. pseudotuberculosis Cor 99/89 (Cps), Cor 100/89 and 2 other strains isolated in our laboratory; C. renale Cor 34/70, Cor 103/90 (Cre) and strains of two species previously classified within corynebacteria, namely Actinomyces pyogenes Cor 65/76 and 3 other strains isolated in our laboratory and Rhodococcus equi Cor 86/85 (Req), Cor 91/88 and 2 other strains isolated in our laboratory.

The CCM strains are deposited in the Czechoslovak Collection of Microorganisms (Kocur et al. 1982) and the Cor, $M$ and Mau strains, in the Czechoslovak National Collection of Type Cultures (Šourek 1990). Strain designation given in the brackets refers to the respective working codes.

\section{Demonstration of Antibacterial Activity}

For demonstration of antibacterial activity the simultaneus technique of cultivation of indicator strains and strains examined or control strains was used. The indicator strains were incorporated into melted agar medium. For demonstration bacteriocin effects living cells of indicator strains were used, for demonstration of bacteriolytic activity use was made of heat-devitalized cells. The technique was described in detail previously (Skalka et al. 1983; Skalka 1992).

\section{Results}

The active strains showed different intensity of effects on the indicator strains. An inhibition zone greater than $5 \mathrm{~mm}$ in diameter (observed in $S$. hyicus and in some control active strains) was scored as very intense. An inhibition zone of 2 to $5 \mathrm{~mm}$ in diameter was scored as intense and that smaller than $2 \mathrm{~mm}$ in diameter was recorded as weak. Where no clearly defined zone was observed, the effect was scored as negative. This scoring system was used in evaluating the effects observed on both living and devitalized cells of the indicator strains. The inhibition zones were generally defined more clearly on living than on dead cells of the indicators as can be seen in Fig. 1 and Fig. 2.

In the first series of our experiments all $S$. hyicus and $S$. chromogenes strains were tested on all the strains of micrococcal species included in the study. The 


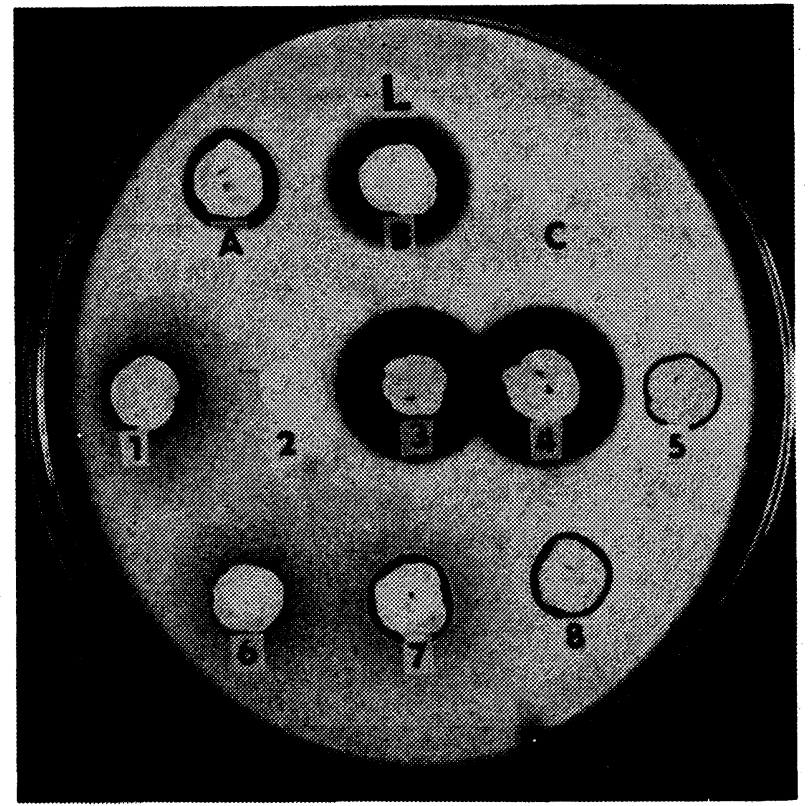

Fig. 1. On agar medium with a suspension of living cells of indicator M. luteus strain Mlu (L)" grow macrocolonies of $S$. aureus UT0007 (A), S. sciuri KPJ III (B), S. simulans K-6-WI (C), S. hyicus 691/87 (1), 887/87 (2), 664/86 (3), 174/87 (4), 695/87 (5) and S. chromogenes $906 / 90$ (6), 709/87 (7), 703/87 (8) strains showing effects of different intensity.

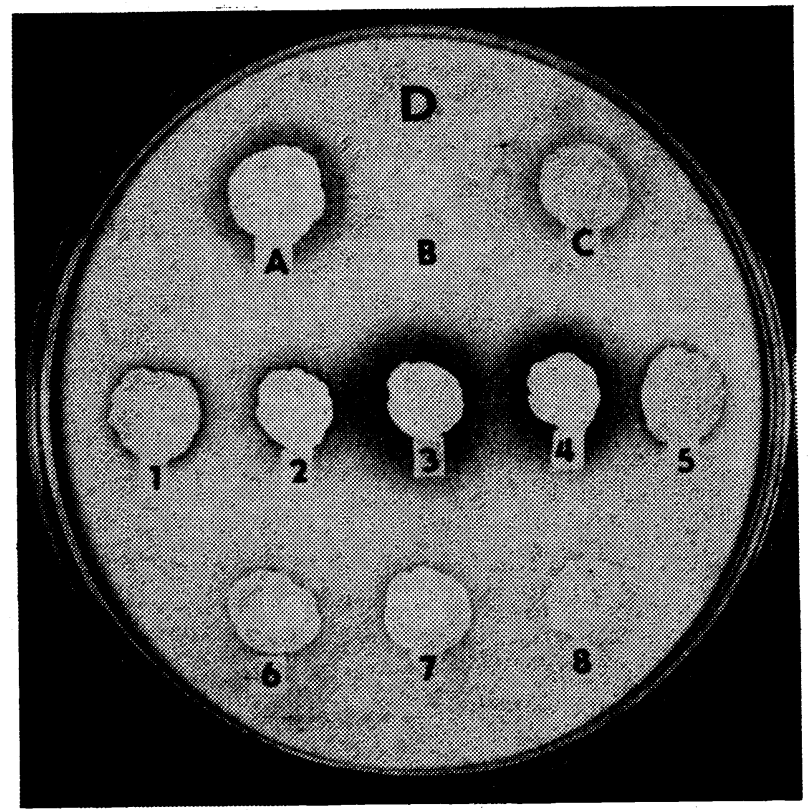

Fig. 2. Effects of the same strains as in Fig. 1 on devitalized cells of indicator M. luteus strain. Mlu (D) suspended in agar medium. 
Table 1

Effects of $S$. hyicus and $S$. chromogenes strains on Micrococcus spp.

\begin{tabular}{|c|c|c|c|c|c|c|c|c|c|c|}
\hline \multirow{2}{*}{ Micrococcus } & \multirow{2}{*}{$\mathbf{n}$} & \multirow{2}{*}{$\mathbf{s}$} & \multicolumn{4}{|c|}{$\underset{\text { n } 40}{\text { S. hyicus }}$} & \multicolumn{4}{|c|}{$\begin{array}{c}\text { S. chromogenes } \\
\mathrm{n} 20\end{array}$} \\
\hline & & & +++ & ++ & + & - & +++ & ++ & + & - \\
\hline luteus & 12 & $\begin{array}{l}\text { L } \\
\mathbf{D}\end{array}$ & $\begin{array}{l}9 \\
7\end{array}$ & $\begin{array}{l}8 \\
4\end{array}$ & $\begin{array}{r}9 \\
15\end{array}$ & $\begin{array}{l}14 \\
14\end{array}$ & $\begin{array}{l}0 \\
0\end{array}$ & $\begin{array}{l}4 \\
0\end{array}$ & $\begin{array}{l}7 \\
9\end{array}$ & 99 \\
\hline lylae & 5 & $\begin{array}{l}\text { L } \\
\text { D }\end{array}$ & $\begin{array}{r}0 \\
21\end{array}$ & $\begin{array}{r}4 \\
16\end{array}$ & $\begin{array}{l}2 \\
3\end{array}$ & $\begin{array}{r}34 \\
0\end{array}$ & $\begin{array}{l}\mathbf{0} \\
\mathbf{0}\end{array}$ & $\begin{array}{r}1 \\
17\end{array}$ & $\begin{array}{l}3 \\
3\end{array}$ & $\begin{array}{r}16 \\
0\end{array}$ \\
\hline roseus & 5 & $\stackrel{\mathbf{L}}{\mathbf{D}}$ & $\begin{array}{l}3 \\
0\end{array}$ & $\begin{array}{l}4 \\
0\end{array}$ & $\begin{array}{l}2 \\
1\end{array}$ & $\begin{array}{l}31 \\
39\end{array}$ & $\begin{array}{l}0 \\
0\end{array}$ & $\begin{array}{l}2 \\
0\end{array}$ & $\begin{array}{l}1 \\
0\end{array}$ & $\begin{array}{l}17 \\
20\end{array}$ \\
\hline kristinae & 1 & $\begin{array}{l}\mathbf{L} \\
\mathbf{D}\end{array}$ & $\begin{array}{l}0 \\
0\end{array}$ & $\begin{array}{l}0 \\
0\end{array}$ & $\begin{array}{l}2 \\
1\end{array}$ & $\begin{array}{l}38 \\
39\end{array}$ & $\begin{array}{l}\mathbf{0} \\
\mathbf{0}\end{array}$ & $\begin{array}{l}\mathbf{0} \\
\mathbf{0}\end{array}$ & $\begin{array}{l}0 \\
0\end{array}$ & $\begin{array}{l}20 \\
20\end{array}$ \\
\hline nishinomiyaensis & 1 & $\begin{array}{l}\mathbf{L} \\
\mathbf{D}\end{array}$ & $\begin{array}{l}\mathbf{0} \\
\mathbf{0}\end{array}$ & $\begin{array}{l}2 \\
0\end{array}$ & $\begin{array}{l}2 \\
1\end{array}$ & $\begin{array}{l}36 \\
39\end{array}$ & $\begin{array}{l}\mathbf{0} \\
\mathbf{0}\end{array}$ & $\begin{array}{l}\mathbf{0} \\
\mathbf{0}\end{array}$ & $\begin{array}{l}\mathbf{0} \\
\mathbf{0}\end{array}$ & $\begin{array}{l}20 \\
20\end{array}$ \\
\hline sedentarius & 3 & $\begin{array}{l}\mathbf{L} \\
\mathbf{D}\end{array}$ & $\begin{array}{r}17 \\
0\end{array}$ & $\begin{array}{r}18 \\
0\end{array}$ & $\begin{array}{l}5 \\
0\end{array}$ & $\begin{array}{r}0 \\
40\end{array}$ & $\begin{array}{l}\mathbf{0} \\
\mathbf{0}\end{array}$ & $\begin{array}{r}17 \\
0\end{array}$ & $\begin{array}{l}3 \\
0\end{array}$ & $\begin{array}{r}0 \\
20\end{array}$ \\
\hline varians & 3 & $\begin{array}{l}\mathbf{L} \\
\mathbf{D}\end{array}$ & $\begin{array}{l}2 \\
0\end{array}$ & $\begin{array}{l}2 \\
0\end{array}$ & $\begin{array}{l}1 \\
0\end{array}$ & $\begin{array}{l}35 \\
40\end{array}$ & $\begin{array}{l}\mathbf{0} \\
\mathbf{0}\end{array}$ & $\begin{array}{l}\mathbf{0} \\
\mathbf{0}\end{array}$ & $\begin{array}{l}0 \\
0\end{array}$ & $\begin{array}{l}20 \\
20\end{array}$ \\
\hline
\end{tabular}

Explanatory notes:

$\mathrm{n}=$ number of strains; $\mathrm{s}=$ status of cells; $\mathrm{L}=$ living cells; $\mathrm{D}=$ dead cells.

Evaluation of inhibition zones: $+++=$ more than $5 \mathrm{~mm},++=2$ to $5 \mathrm{~mm},+=$ less than $2 \mathrm{~mm}$ in diameter; $-=$ no effect.

results obtained in this series are summarized in Table 1 which, however, does not include the differences between the individual active and indicator strains observed within the individual groups of intensity of the effects. The activity of $S$. hyicus strains on living and devitalized $M$. luteus strains was the same; only $35 \%$ of the strains were inactive. S. chromogenes strains showed less intense effects on $M$. luteus: $45 \%$ and $55 \%$ of the strains produced no effects on $M$. luteus living and devitalized cells, respectively. All $S$. hyicus and $S$. chromogenes strains produced effects on $M$. sedentarius living cells but were entirely inactive towards devitalized cells of this species. An opposite effect was recorded for M. lylae: all $S$. hyicus and $S$. chromogenes strains affected its dead cells, whereas only $15 \%$ of $S$. hyicus strains and $20 \%$ of $S$. chromogenes strains exerted their effects on living $M$. lylae cells. Both $S$. hyicus and $S$. chromogenes had very weak effects on $M$. roseus, $M$. varians, $M$. kristinae and $M$. nishinomiyaensis; nevertheless, the effects on living cells of these micrococcal species were invariably slightly higher.

On the basis of the results obtained in the first series of our experiments the strains included in the second series were as follows: $7 \mathrm{~S}$. hyicus strains, $3 \mathrm{~S}$. chromogenes strains and 1 strain each of the micrococcal species. The active set was extended by including strains UT0007, KPJ III and K-6-WI that are known as producers of antibacterial exosubstances. The set of indicator strains was extended by including $5 S$. aureus strains, $2 S$. intermedius strains, $1 \mathrm{~S}$. haemolyticus strain and 4 strains each of $S$. agalactiae, $S$. uberis, $S$. equi, $C$. pseudotuberculosis, $A$. pyogenes, $R$. equi and $2 C$. renale strains. The sensitivity of the indicators was tested using their living and devitalized cells.

The activity of $S$. hyicus and $S$. chromogenes strains corresponded to the aforegoing observations. Of the active controls, UT0007 produced effects on living cells of $M$. luteus, $M$. roseus and $M$. sedentarius and on devitalized cells of $M$. luteus and M. lylae; in the remaining tests with micrococci it was inactive. KPJ III 
produced intense effects on living cells of $M$. luteus, $M$. lylae, $M$. roseus and $M$. kristinae but had no effect on living cells of the remaining three micrococcal species and on dead cells of the micrococcal indicators. K-6-WI had only weak effects on living cells of $M$. sedentarius and on devitalized cells of $M$. luteus and $M$. lylae; in the remaining tests with micrococci it was inactive.

$S$. hyicus strain $664 / 86$ produced effects on living cells of all staphylococcal, streptococcal and corynebacterial indicators, but in tests with their devitalized cells it was inactive except a weak effect on streptococci. A similar pattern of activity with less intense effects was recorded for strain 174/87. An antibacterial activity on $S$. aureus strains of a higher intensity of effects than that shown by strain $664 / 86$ was recorded for $S$. hyicus strain $695 / 87$ which, as the only one of the $S$. hyicus and $S$. chromogenes strains, affected also $S$. aureus devitalized strains. However, this strain was inactive on streptococcal and corynebacterial indicators. Of the other $S$. hyicus strains only strain 173/87 exerted weak effects on living cells of some staphylococcal and corynebacterial indicators. The remaining $S$. hyicus strains were entirely inactive on staphylococcal, streptococcal and corynebacterial indicators. Of $S$. chromogenes strains only strain $709 / 87$ affected living cells of some staphylococcal, streptococcal and corynebacterial indicators. The other two strains of this species were inactive towards these indicators.

Among the active strains used as controls strain KPJ III showed the widest spectrum and a high intensity of effects, but only on living cells. Strain UT0007 affected only living cells of $S$. aureus, $C$. pseudotuberculosis, $C$. renale and $A$. pyogenes. Strain K-6-WI exerted intense effects on both living and devitalized cells of staphylococci but was inactive on the remaining indicators.

The results of the second series of experiments are presented in Table 2.

\section{Discussion}

Apart from the report by Balusek and Hájek (1985) the attention of the relevant studies was centred mainly on lytic effects of $S$. hyicus. Therefore our study covered also those effects of $S$. hyicus and $S$. chromogenes that have received little attention so far, namely their effects on living indicator cells in continuation of our previous observatios (Skalka 1988), together with investigation of their effects on devitalized cells of indicator strains. The spectrum of indicators included in our study was wider than that described by other writers dealing with antibacterial effects of the two species. For the sake of comparison we also used producers of known staphylococcal exosubstances, namely bacteriocin $\mathbf{B a c R}_{1}$, staphylococcin having a wide-spectrum effect, and lysostaphin.

In the first series of our experiments conducted with micrococci it became clear that the activity of the two species under study as well as the sensitivity of the indicators varied from strain to strain and this observation was then confirmed in the second series of our experiments. The differences in effects were both quantitative (expressed in terms of their intensity) and qualitative (expressed as either positive or negative effect). In comparing our data with those reported by other writers consideration should be given to the fact that we tested different strains and used different indicator strains, the only exception being $M$. luteus strain CCM 169 which was used by Frede et al. (1989) and Lämmler (1989, $1991 \mathrm{a}, 1991 \mathrm{~b}$ ). Some influence on the differences of the results may also be ascribed to the culture medium; the possible role of culture medium in this respect was pointed out by Varaldo et al. (1978a, 1978b) in their studies of lyso- 
Table 2

Antibacterial activity of $S$. hyicus, $S$. chromogenes

\begin{tabular}{|c|c|c|c|c|c|c|c|c|c|c|}
\hline Active strains ( $\left.{ }^{*}\right)$ & & Mlu & Mly & Mro & Mkr & Mni & Mse & Mva & \multicolumn{2}{|c|}{$\underset{\text { Sa1 }}{\text { Indicator }}$} \\
\hline $664 / 86$ & L & $\begin{array}{l}++ \\
+++\end{array}$ & $\begin{array}{r}++ \\
++\end{array}$ & ++ & \pm & ++ & +++ & +++ & ++ & ++ \\
\hline $174 / 87$ & $\mathbf{L}$ & $++t$ & ++ & +++ & - & ++ & +++ & ++ & - & + \\
\hline $173 / 87$ & $\mathbf{L}$ & $\begin{array}{l}+++ \\
+++\end{array}$ & ++ & $+\overline{+}$ & - & $\overline{+}$ & $++\overline{+}$ & $\overline{-}$ & $\overrightarrow{+}$ & $\overrightarrow{+}$ \\
\hline $691 / 87$ & $\underset{L}{D}$ & $\begin{array}{l}++ \\
++\end{array}$ & + \pm & $\bar{z}$ & - & $\bar{z}$ & $+\bar{t}$ & $\bar{z}$ & - & $\overline{-}$ \\
\hline & $\overrightarrow{\mathrm{D}}$ & + & +++ & - & - & - & - & - & - & - \\
\hline $695 / 87$ & L & + & - & - & - & - & +++ & - & +++ & +++ \\
\hline $687 / 87$ & $\mathbf{L}$ & + & $T_{-}^{T}$ & - & - & - & +++ & - & - & -1 \\
\hline $807 / 07$ & D & + & +++ & - & - & - & - & - & - & - \\
\hline (oortor & D & + & +++ & - & - & - & \pm & $=$ & - & - \\
\hline $709 / 87$ & $\mathbf{L}$ & ++ & ++ & ++ & - & -- & ++ & - & + & + \\
\hline $703 / 87$ & D & $+t$ & ++ & - & - & $\overline{-}$ & $1+$ & - & - & $\pi$ \\
\hline $103 / 81$ & L & + \pm & $+\overline{+}$ & $\overline{-}$ & $\bar{z}$ & $\overline{-}$ & + \pm & $\bar{z}$ & - & $=$ \\
\hline 906/90 & $\mathbf{L}$ & - & - & - & - & - & ++ & - & - & - \\
\hline & & & & & & & & & & \\
\hline UT0007 & L & ++ & - & ++ & - & - & + & - & +++ & +++ \\
\hline KPJ III & L & $\begin{array}{l}+++ \\
+++\end{array}$ & $\begin{array}{l}++ \\
++\end{array}$ & $++\bar{t}$ & ++ & - & - & 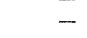 & +++ & +++ \\
\hline & D & - & - & & & $\begin{array}{ll}- \\
-\end{array}$ & - & - & & \\
\hline$K-6-W I$ & $\mathrm{~L}$ & - & - & - & - & - & + & - & +++ & ++ \\
\hline & D & + & + & - & - & - & - & - & +++ & + \\
\hline
\end{tabular}

Explanatory notes:

$*$ = code designation of the strains in the author's laboratory collection; $\mathrm{L}=$ living cells of indicator strains; $\mathrm{D}=$ dead cells of indicator strains.

zyme activity of staphylococci. In our experiments the effects were substantially less pronounced on Blood Agar Base No. 4 medium than on Brain Heart Infusion Agar which we then used consistently and which was also used by Balusek and Hájek (1985). Other writers preferred the use of Tryptone Soya Agar.

In the first series of our experiments unequivocal results were obtained only for $M$. sedentarius strains the living cells of which were affected by all $S$. hyicus and $S$. chromogenes strains which, however, were inactive on devitalized cells of this species. An opposite, though not so unequivocal, effect was recorded for $M$. lylae the dead cells of which were lysed by all $S$. hyicus and $S$. chromogenes strains, whereas its living cells were affected by only a few strains of the two species. Differences in activity were found on both living and dead cells of $M$. luteus and not even strain CCM 169 was affected by all $S$. hyicus and S. chromogenes strains. This fact represents the greatest difference of our results from those reported by Lämmler $(1989,1991 \mathrm{a})$.

The differences in antibacterial activity between the individual $S$. hyicus and $S$. chromogenes strains were even more pronounced in the second series of our experiments. It became apparent that within each of the two species there exist strains that can affect particularly living cells of micrococci, staphylococci, streptococci and corynebacteria along with strains lacking this characteristic or strains markedly active towards both living and dead cells of $S$. aureus. These observations 
and control active strains on indicator strains

\begin{tabular}{|c|c|c|c|c|c|c|c|c|c|c|c|c|}
\hline $\begin{array}{l}\text { strains } \\
\text { Sa3 }\end{array}$ & $\stackrel{(*)}{\text { Sa4 }}$ & Sa5 & Sil & $\mathrm{Si} 2$ & Sh1 & Sag & Sub & Seq & Cps & Cre & Apy & Req \\
\hline++ & ++ & ++ & ++ & ++ & ++ & +++ & +++ & ++ & ++ & ++ & ++ & ++ \\
\hline $\bar{t}$ & $+\bar{t}$ & $+\bar{t}$ & $\bar{t}$ & $\overline{-}$ & $\overline{-}$ & $++\stackrel{+}{+}$ & $++\stackrel{+}{+}$ & $\stackrel{+}{+}$ & $+\overline{+}$ & $+\overline{+}$ & $+\overline{+}$ & $+\overline{+}$ \\
\hline- & - & - & - & - & - & & & + & - & - & - & - \\
\hline+ & + & + & - & - & - & - & - & - & + & + & + & ++ \\
\hline- & - & - & - & $=$ & - & - & - & - & - & - & - & - \\
\hline$\overline{-}$ & = & z & $\bar{z}$ & $\bar{z}$ & $=$ & $=$ & z & $=$ & \pm & \pm & \pm & I \\
\hline$++t$ & +++ & +++ & $=$ & - & - & - & - & - & - & - & $=$ & $\overline{-}$ \\
\hline$++t$ & $++t$ & $+t+$ & + & - & + & - & - & - & - & - & - & - \\
\hline- & 1 & - & - & - & - & - & - & - & - & - & - & - \\
\hline- & - & - & - & - & - & - & - & - & - & - & - & - \\
\hline$=$ & $=$ & = & $\bar{z}$ & $\bar{z}$ & $=$ & $=$ & $=$ & $=$ & $=$ & $=$ & $=$ & $\overline{-}$ \\
\hline & & & & & & & & & & & & \\
\hline+ & + & + & - & - & - & ++ & ++ & - & - & + & + & + \\
\hline- & - & - & - & - & - & - & - & - & - & 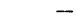 & 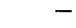 & - \\
\hline- & - & - & - & - & - & - & - & - & - & - & - & - \\
\hline $\bar{z}$ & $=$ & - & z & $=$ & $=$ & $=$ & $=$ & $=$ & - & - & $=$ & - \\
\hline- & - & - & $=$ & - & - & - & - & I & 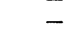 & - & - & $\overline{-}$ \\
\hline+++ & +++ & +++ & - & - & - & - & - & - & + & +++ & ++ & - \\
\hline$++\overline{+}$ & $++\overline{+}$ & $++\overline{+}$ & $++\bar{t}$ & $++\bar{t}$ & $++\bar{t}$ & $+\overline{+}$ & $++\bar{t}$ & +++ & $\bar{t}$ & +++ & +++ & $+\overline{+}$ \\
\hline+++ & +++ & ++ & ++ & ++ & + & - & - & - & - & - & - & - \\
\hline+++ & +++ & +++ & +++ & +++ & + & - & - & - & - & - & - & - \\
\hline
\end{tabular}

Evaluation of inhibition zones: $+++=$ more than $5 \mathrm{~mm},++=2$ to $5 \mathrm{~mm},+-$ less than $2 \mathrm{~mm}$ indiameter; $-=$ no effect.

confirmed and extended the data reported by Balusek and Hájek (1985). The differences between our results with devitalized cells of streptococci and the descriptions reported by other writers (Müller and Blobel 1987; Frede et al. 1989; Lämmler and Wibawan 1990) can be accounted for by the different form of active exosubstance. The afore-metioned writers used the purified fraction LE IIIb, which is a procedure more demanding in terms of technique and cost than the use of the substance produced by the growing strain "in situ" in our study.

The effects of strains UT0007 and K-6-WI did not differ from those described previously (Schindler and Schuhardt 1964; Skalka et al. 1983). Strain KPJ III showed the widest spectrum and the highest intensity of effects but affected only living cells of the indicator strains. Its antibacterial effects on living cells is comparable to those of strains $664 / 86$ and $174 / 87$ but differs from them by its inactivity on devitalized cells.

Our finding of the lack of uniform action of $S$. hyicus and $S$. chromogenes strains on living and dead cells of $M$. luteus prevents us from agreeing with the recommendation advanced by Lämmler $(1989,1991 \mathrm{a})$. On the other hand, the uniform antibacterial effects of all $S$. hyicus and $S$. chromogenes strains on living $M$. sedentarius and dead $M$. lylae cells could be used in routine diagnostic work. However, tests less demanding in terms of technique and cost are available by which $S$. hyi- 
cus and S. chromogenes can be diagnosed (Skalka 1991a, 1991b). Nevertheless, studies of the antibacterial effects are of practical value for detailed characteristics of isolated $S$. hyicus and $S$. chromogenes strains, particularly for epizootiological purposes.

\section{Antibakteriální účinky Staphylococcus hyicus a Staphylococcus chromogenes}

Antibakteriální účinky Staphylococcus hyicus (n 40) a Staphylococcus chromogenes (n 20) se sledovaly na živých a tepelně devitalizovaných buňkách mikrokokových, stafylokokových, streptokokových a korynebakteriálních indikátorových kmenů. Všechny kmeny $S$. hyicus a $S$. chromogenes inhibovaly růst Micrococcus sedentarius a lyzovaly usmrcené buňky Micrococcus lylae, nepưsobily však na mrtvé buňky $M$. sedentarius a jen ojedinělé inhibovaly růst $M$. lylae. Jen malý počet kmenů $S$. hyicus působil intenzívně na živé indikátory a velmi slabě na jejich mrtvé buňky. Aktivita některých kmenů $S$. chromogenes, zjištěná vesměs na živých indikátorech, nedosahovala intenzity zjištěné $\mathrm{u}$ aktivních kmenů $S$. hyicus. Většina kmenů $S$. hyicus a $S$. chromogenes byla na použitých indikátorech inaktivní. Pozorovaná antibakteriální aktivita se určila jako individuální vlastnost jednotlivých kmenů, nikoliv jako obecná vlastnost druhů $S$. hyicus a $S$. chromogenes.

\section{Антибактериальное воздействие Staphylococcus hyicus и Staphylococcus chromogenes}

Проводили исследования антибактериального воздействия Staphylococcus hyicus (n 40) и Staphylococcus chromogenes (n 20) на живых и температурно умерщвленных клетках микрококковых, стафилококковых, стрептококковых и коринебактериальных индикаторных штаммов. Все штаммы S. hyicus и S. chromogenes ингибировали рост Micrococcus sedentarius и лизировали умерщвленные клетки Micrococcus lylae, однако они не оказывали влияния на мертвые клетки M. sedentarius и только в отдельных случаях ингибировали рост M. lylae. Только незначительное число штаммов S. hyicus действовало интенсивно на живые индикаторы и весьма невыразительно на их мертвые клетки. Активность некоторых штаммов S. chromogenes, установленная большей частью на живых индикаторах, не достигала интенсивности, установленной у активных штаммов S. hyicus. Большинство штаммов S. hyicus и S. chromogenes на использованных индикаторах отличалась неактивностью. Наблюдаемую антибактериальную активность определяли как индивидуальное свойство отдельных штаммов, а не как общее свойство видов S. hyicus и S. chromogenes.

\section{References}

BALUSEK, J.-HÁJEK, V.: Antagonistic activities of coagulase-positive staphylococci. J. Hyg. Epidemiol. Microbiol. Immunol., 28, 1985: 147-154

FREDE, C. -CHRIST, D.-LÄMMLER, C.: Streptolytic activities of a lytic enzyme from Staphylococcus hyicus. Zbl. Bakt., 271, 1989: 54-60 
FREDERICQ, P.: Sur la sensibilité et l'activité antibiotique des Staphylocoques. C. R. Soc.Biol. Paris, 140, 1946: $1167-1170$

HALBERT, S. P.-SWICK, L. S. - SONN KAZAR, C.: Characteristics of antibiotic-producing. strains of the ocular bacterial flora. J. Immunol., 70, 1953; 400-410

IVÁNOVICS, G.: Bacteriocins and bacteriocin-like substances. Bacteriol. Rev., 26, 1962: 108. to 118

KOCUR, M.-PÁČOVÃ, Z.-SOVADINA, M.: Catalogue of cultures. I. Bacteria. Czechoslovak Collection of Microorganisms Brno, 1982. $213 \mathrm{p}$.

LÄMMLER, C.: Characteristic bacteriolytic activities of Staphylococcus hyicus. J. Clin. Microbiol., 27, 1989: $1682-1683$

LÄMMLER, C.: Characterization of Staphylococcus hyicus with the ATB 32 Staph System and with conventional tests. J. Clin Microbiol., 29, 1991(a): 1 221-1224

LAMMLER, C.: Comparative studies on bacteriolytic properties of Staphylococcus chromogenes and Staphylococcus hyicus. J. Vet. Med. B 38, 1991(b): 468-472

LÄMMLER, C.-WIBAWAN, I. W. T.: Solubilization of group and type-specific streptococcal antigens with a murolytic enzyme from Staphylococcus hyicus. J. Vet. Med. B 37, 1990: $173-176$

MÚLLER, H. P.-BLOBEL, H.: Isolation and characterization of a staphylococcal enzyme bacteriolytic on streptococci. Zbl. Bakt. Hyg., A 264, 1987: 41-48

SCHINDLER, C. A. - SCHUHARDT, V. T.: Lysostaphin: a new bacteriolytic agent for theStaphylococcus. Proc. Natl. Acad. Sci. USA, 51, 1964: 414-421

SKALKA, B.: Isolation of Staphylococcus hyicus strains from healthy hosts and a diagnostic study of the strains (orig. in Czech). Veter. Med. (Praha), 33, 1988: 607-616

SKALKA, B.: Antagonistic effect of Staphylococcus hyicus and Staphylococcus chromogenes exhibited on staphylococcal delta hemolysin. Acta vet. Brno, 60, 1991(a): 61-69

SKALKA, B.: Diagnostic value of the characteristics of Staphylococcus hyicus and Staphylococcus chromogenes. Acta vet. Brno, 60, 1991(b): 227-283

SKALKA, B.: Bactericidal and bacteriolytic activity of Listeria. Acta vet. Brno, 61, 1992: 23-28.

SKALKA, B.-PILLICH, J.-POSPÍŠIL, L.: New possibilities of staphylococcin detection. in the exfoliatin-producing strains of Staphylococcus aureus. Zbl. Bakt. Hyg., I. Abt. Orig. A 254, 1983: $34-41$

SU, T. L.: Micrococcin. An antibacterial substance formed by a strain of Micrococcus. Brit. J. Exp. Pathol., 29, 1948: 473-481

Sourek, J.: Catalogue of pathogenic microorganisms. Czechoslovak National Collection of Type Cultures. Prague. 1990, 134 p.

VARALDO, P. E.-SATTA, G.-GRAZI, G.-ROMANZI, C. A.: Grouping of staphylococci on the basis of their bacteriolytic-activity patterns: a new approach to the taxonomy of the Micrococcaceae. I. Identification of six different "lyogroups". Int. J. Syst. Bacteriol., 28, 1978 (a): $141-147$

VARALDO, P. E. - SATTA, G.-HÁJEK, V.: Taxonomic study of coagulase-positive staphylococci: bacteriolytic activity pattern analysis. Int. J. Syst. Bacteriol., 28, 1978 (b): 445-448: WELSCH, M.: Le "lysozyme" des staphylocoques. C. R. Soc. Belg. Biol., 153, 1959: 2 080-2 083。 